\title{
Amadeus
} International Multidisciplinary Journal IISSN 2525-8281

DOI: $10.14295 / a i m j . v 5 i 9.128$

\section{Donation and Transplantation of Organs and Tissues in a Bioethic Dimension: A Systematic Review}

Ana Maria Lima Carneiro de Andrade ${ }^{l}$,

Caroline Pereira Modesto ${ }^{2}$,

Lucas Tavares Cruz de

Albuquerque ${ }^{3}$,

Taelis Araujo Granja ${ }^{4}$, Ana Beatriz Tavares Cruz de Albuquerque ${ }^{5}$

Cláudio Gleidiston Lima da Silva ${ }^{6}$

Djailson Ricardo Malheiro ${ }^{7}$

\begin{abstract}
Organs and tissue transplantation between humans is a relatively current tool in medical practice and is based on the implantation of a solid organ or tissue from a living donor or corpse to a receiver. From the transplantation practice on an ascending scale practiced all over the world, linked to the growing demand for the health system, emerged the need to implement normative ethical concepts to regulate these procedures. Methodology: It is a systematic review whose data were extracted from the PubMed and VHL databases. In the first one, the descriptors "bioethics" and "organ transplantation" were used using the logical operator AND that resulted in 731 articles and, after refinement, the sample registered 02 (two) articles. In the second cited base, the search was performed with the same descriptors $(n=536)$, but only 07 were selected. Results: We emphasize the transplantation concept and its attributions, besides exploring legislative changes in Brazil and in the world, ethical and bioethical debates on the subject and the medical-legal panel involved. Conclusion: Faced with the death expectation, organ transplantation emerges as a safe method with the potential to increase longevity and quality of the patient life, nevertheless, ethical dilemmas arise in this process.
\end{abstract}

Keywords: Bioethics. Tissues and organs obtainment. Organ transplantation.

\footnotetext{
${ }^{1}$ Medical Student at Faculdade de Medicina Estácio Juazeiro do Norte (Estácio-FMJ); anafaculdadem30@gmail.com ${ }^{2}$ Medical Student at Faculdade de Medicina Estácio Juazeiro do Norte (Estácio-FMJ); carolinepmodesto@hotmail.com

${ }^{3}$ Medical Student at Faculdade de Medicina Estácio Juazeiro do Norte (Estácio-FMJ); lucastavares47@ gmail.com

${ }^{4}$ Doctor by Faculdade de Medicina Estácio Juazeiro do Norte (Estácio-FMJ); taelisaraujo@ hotmail.com

${ }^{5}$ Medical Student at Faculdade de Medicina de Olinda (FMO); biatavarees@hotmail.com

${ }^{6}$ Professor at Faculdade de Medicina Estácio Juazeiro do Norte (Estácio-FMJ) / Universidade Federal do Cariri (UFCA); claudio.gleidiston@ufca.edu.br

${ }^{7}$ Professor at Faculdade de Medicina Estácio Juazeiro do Norte (Estácio-FMJ).djailsonricardo@ gmail.com
} 


\title{
Doação e Transplante de Órgãos e Tecidos em uma Dimensão Bioética: Uma Revisão Sistemática
}

\begin{abstract}
Resumo: O transplante de órgãos e tecidos entre seres humanos é uma ferramenta relativamente atual na prática médica e baseia-se no implante de um órgão ou tecido sólido de um doador ou cadáver vivo para um receptor. A partir da prática de transplante em escala ascendente praticada em todo o mundo, atrelada à crescente demanda pelo sistema de saúde, emergiu a necessidade de implementar conceitos éticos normativos para regular esses procedimentos. Metodologia: é uma revisão sistemática cujos dados foram extraídos dos bancos de dados PubMed e BVS. No primeiro, foram utilizados os descritores "bioética" e "transplante de órgãos", utilizando o operador lógico AND que resultou em 731 artigos e, após aperfeiçoamento, a amostra registrou 02 (dois) artigos. Na segunda base citada, a busca foi realizada com os mesmos descritores $(n=536)$, mas apenas 07 foram selecionados. Resultados: Enfatiza-se o conceito de transplante e suas atribuições, além de explorar mudanças legislativas no Brasil e no mundo, debates éticos e bioéticos sobre o assunto e o painel médico-jurídico envolvido. Conclusão: Diante da expectativa de morte, o transplante de órgãos surge como um método seguro, com potencial para aumentar a longevidade e a qualidade de vida do paciente, no entanto, surgem dilemas éticos nesse processo.
\end{abstract}

Palavras-chave: Bioética. Obtenção de tecidos e órgãos. Transplante de

\section{Introduction}

Bioethics is considered an instrument of knowledge and analysis of medical practice from a moral perspective, embracing the implication of technoscientific progress. Moral and ethical dilemmas arise along with technological developments in the health area, instigating the debate on the limits of professional dynamics (Nunes, 2017) (Victorino \& Ventura, 2017).

Organs and tissue transplantation between humans is a relatively current tool in medical practice and is based on the implantation of a solid organ or tissue from a living donor or corpse to a receiver. The introduction of modern techniques of preservation and viability of viscera added to the immunosuppressive drugs allows, in a long term, the survival of the transplanted tissue and/or organ (Lara \& Rojas, 2014).

Batista and Seidl (2017) refer to immunological research as a scientific progress that has enabled a decrease in organ and tissue rejection rates. Associated with the advent of immunosuppressive drugs, standardization of the removal process of cadaveric donor organs and solutions application for organs preservation, the transplantation procedures were spread around the world. The first transplantation procedure performed in Brazil was described in 
1965 with renal organ; since then, a legislation was introduced and, later, the Notification Central of Organs and Tissues in 1991. The National Transplantation System (SNT) notes that the Brazilian State's transplant program presents a highly performance compared to other transplantation systems beyond borders, having kidney, liver, and corneas as the main transplanted organs (Batista \& Seidl, 2017).

The reduction of the effective supply of organ and tissue transplantation is associated with the omission of the public power related to a management failure, even with the recognition of the ethical subject vulnerability (Santos; Hossne \& Anjos, 2017).

Caplan (2014) relates the discouragement to the donation of corps organs with aesthetics, affective relationship, and religious prejudices. A study conducted by Batista and Seid (2017) demonstrated a $15.7 \%$ percentage result in refusal to donate organs and tissues for transplants. The donor incomprehension presented $48.6 \%-23 \%$ for donor refusal in life, $17.6 \%$ family craving to maintain the anatomical integrality, $1.4 \%$ for dogmas and religious ideologies and $9.4 \%$ do not present justification to the donor refusal.

From the transplantation practice in an ascending scale practiced all over the world, linked to the growing demand for the health system, emerged the need to implement normative ethical concepts to regulate these procedures, having as objectives: to establish a standardization of the death diagnosis, authorization format, agreement for use of cadaveric donor bodies or living donor organs, limitation to the use of organs of living donors without kinship, hospitals and health teams authorization, the avoidance of for-profit merchandising and the implementation of penalties (Batista \& Seidl, 2017).

\section{Methodology}

It is a systematic review, addressing primary studies published in two databases: PubMed (US National Library of Medicine National Institutes of Health) and VHL (Virtual Health Library). The first search was on PubMed on August 26, 2018 at 10:48 a.m. The descriptors used were "Bioethic" [Mesh] and "Organ transplantation" [Mesh] combined by the boolean operator AND that resulted in 731 articles - the final filtering obeying the inclusion and exclusion criteria totaled a sample of 02 works. The second search was on VHL also on August 26, 2018 at 11:03 a.m. using the descriptors "bioethics" and "organ transplants" formalized in Decs (Descriptors in health sciences) and articulated by the logical 
operator AND. The research culminated in 536 articles, resulting in 07 articles after scrutiny (figure 1).

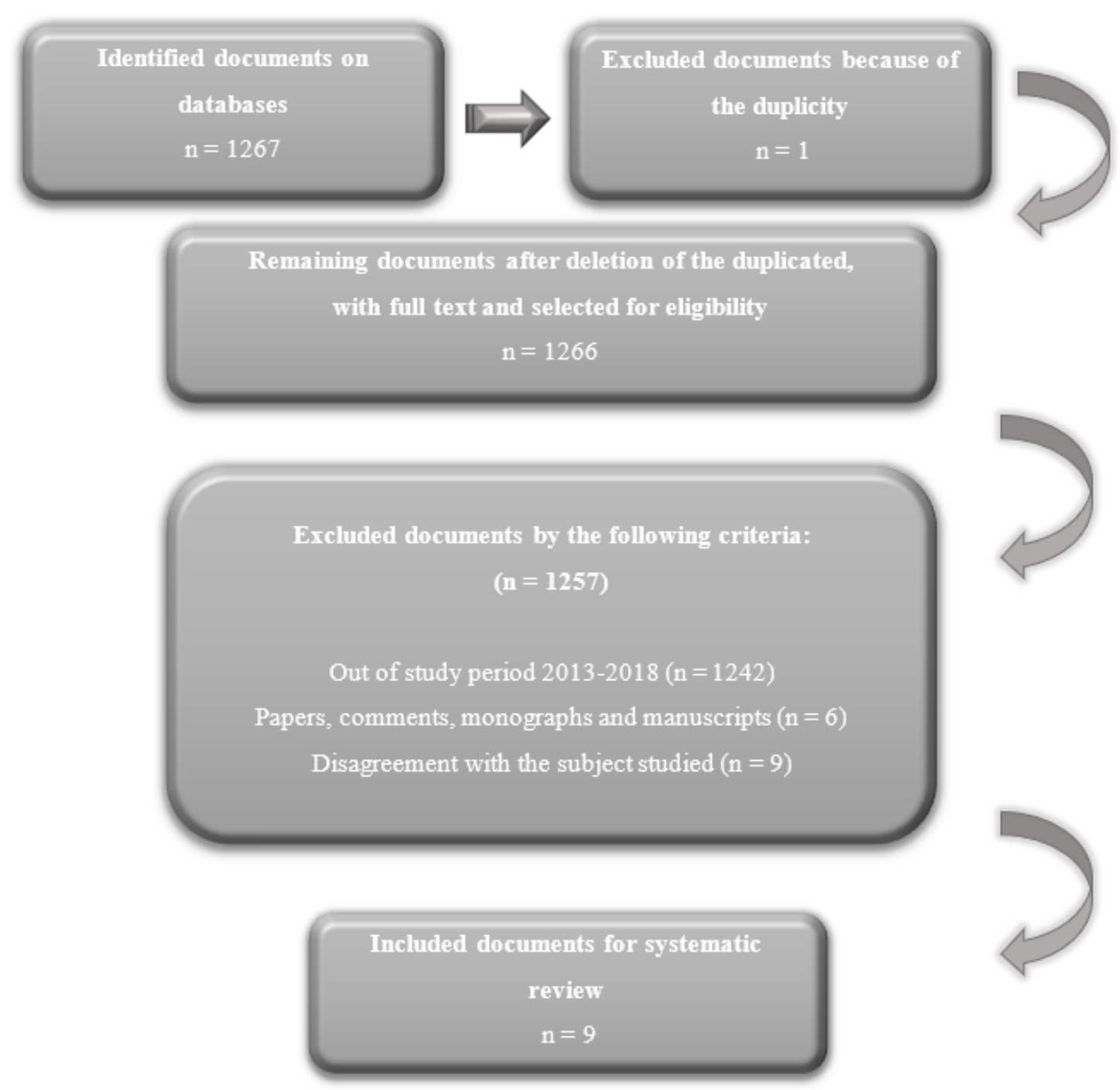

Figure 1. Schematization of methods. Source: Andrade et al., 2020

\section{Results}

A general summary of the articles studied is presented, as well as a description of the authors, year of publication, objectives, and main principles (Table 1). 
Table 1 - General summary of the articles studied.

\begin{tabular}{|c|c|c|}
\hline Authors & Objectives & Main conclusions \\
\hline (Avello \& Santos, 2014) & $\begin{array}{l}\text { Reflect on the legitimacy of } \\
\text { combining two complex ethical } \\
\text { decisions in the same process: } \\
\text { the withdrawal of life support } \\
\text { techniques (RTSV) and the } \\
\text { limitation of therapeutic effort } \\
\text { (LET) and the possibility of } \\
\text { considering these patients as } \\
\text { organs donors. }\end{array}$ & $\begin{array}{l}\text { Multiple organ donation } \\
\text { according to type III protocols } \\
\text { is a particular kind of donation. } \\
\text { They don't share some of its } \\
\text { characteristics with other forms } \\
\text { of donation and, therefore, they } \\
\text { aren't comparable to those } \\
\text { made up until the present } \\
\text { moment in our country. The } \\
\text { determining factor is the } \\
\text { consideration of the future } \\
\text { donor who needs his own } \\
\text { planning and actions while he } \\
\text { remains alive and the way to } \\
\text { determine the exact moment of } \\
\text { his death. }\end{array}$ \\
\hline (Batista \& Seidl, 2017) & $\begin{array}{l}\text { Bioethical analysis of facial } \\
\text { transplantation. Proposing a } \\
\text { description of the face } \\
\text { transplants situation in the } \\
\text { world and in Brazil, the } \\
\text { importance of the human face } \\
\text { and the human face as a vital } \\
\text { organ. }\end{array}$ & $\begin{array}{l}\text { The facial transplantation } \\
\text { theme has fragile limits } \\
\text { between research ethics, } \\
\text { clinical bioethics, and ethics } \\
\text { related to minorities, especially } \\
\text { regarding to aspects related to } \\
\text { the protection of research } \\
\text { participants or surgeries, like } \\
\text { who would be responsible for } \\
\text { the research costs or procedure } \\
\text { and how the } \\
\text { immunosuppressants would be } \\
\text { guaranteed throughout life, as } \\
\text { well as how the transplant } \\
\text { waiting list would be built and } \\
\text { what criteria and who would } \\
\text { make that call, since facial } \\
\text { transplantation encompasses } \\
\text { particularities regarding to } \\
\text { ethnicity, blood type, sex, race, } \\
\text { facial morphological aspects. }\end{array}$ \\
\hline (Lara \& Rojas, 2014) & $\begin{array}{l}\text { Review and compare the } \\
\text { Chilean situation with the } \\
\text { Spain situation and analyze } \\
\text { some bioethical aspects that } \\
\text { arise with this process. }\end{array}$ & $\begin{array}{l}\text { Governments are striving to } \\
\text { ensure that this distribution of } \\
\text { organs is equitable, efficient } \\
\text { and transparent. In the case of } \\
\text { Chile, for example, to meet } \\
\text { these criteria, there is a single } \\
\text { waiting list for receivers, } \\
\text { centralized at the national level. }\end{array}$ \\
\hline
\end{tabular}




\begin{tabular}{|c|c|c|}
\hline (Caplan, 2014) & $\begin{array}{l}\text { Discuss the organ } \\
\text { transplantation bioethics. }\end{array}$ & $\begin{array}{l}\text { Switch to defined efficacy as } \\
\text { increasing the chances of } \\
\text { saving lives and saving the } \\
\text { majority of years of life, } \\
\text { although it isn't the exclusive } \\
\text { value for rationing, it seems to } \\
\text { make more the moral sense in } \\
\text { confrontation with the limited } \\
\text { resources. Change the public } \\
\text { policy to expand these limited } \\
\text { resources and minimize } \\
\text { scarcity is a powerful } \\
\text { requirement in any situation } \\
\text { where rationing exists, } \\
\text { including transplantation. }\end{array}$ \\
\hline (Coffman \& Siemionow, 2014) & $\begin{array}{l}\text { Discuss the ethical aspects of } \\
\text { face transplantation. }\end{array}$ & $\begin{array}{l}\text { Ethical principles suggest that } \\
\text { collaborative work needs to be } \\
\text { done to capture relevant details } \\
\text { about medical and } \\
\text { psychological results in this } \\
\text { new field to determine if the } \\
\text { risks outweigh the benefits of } \\
\text { this procedure over time. }\end{array}$ \\
\hline (Felipe, 2014) & $\begin{array}{l}\text { Evaluate the teeth origin used } \\
\text { in an ethical and legal } \\
\text { perspective by the students of } \\
\text { the Dentistry course of the } \\
\text { Southern University of Santa } \\
\text { Catarina - Unisul. }\end{array}$ & $\begin{array}{l}\text { This study results reveal the } \\
\text { existence of the teeth trade } \\
\text { among the students of an } \\
\text { undergraduate Dentistry course } \\
\text { of a university in Brazil, as } \\
\text { well as that teachers don't } \\
\text { require the certification of the } \\
\text { teeth origin, so that most of the } \\
\text { elements used don't meet the } \\
\text { ethical, legal and biosafety } \\
\text { requirements for the use of } \\
\text { human organs. }\end{array}$ \\
\hline (Nunes, 2017) & $\begin{array}{l}\text { Identify the thematic choices of } \\
\text { the students of a Nursing } \\
\text { course during the teaching of } \\
\text { bioethics and discuss possible } \\
\text { changes or differences during } \\
\text { the graduation years. }\end{array}$ & $\begin{array}{l}\text { The bioethics teaching-learning } \\
\text { is in a territory close to the } \\
\text { values of citizenship and we } \\
\text { need citizents and professionals } \\
\text { who exercise their faculty of } \\
\text { judgment, who know how to } \\
\text { think and discern, see problems } \\
\text { from the community } \\
\text { perspective, participate and } \\
\text { commit themselves with } \\
\text { themselves, with others and } \\
\text { with the world. }\end{array}$ \\
\hline $\begin{array}{c}\text { (Santos; Hossne \& Anjos, } \\
\text { 2017) }\end{array}$ & $\begin{array}{l}\text { Analyze if managers have } \\
\text { contributed to the increased } \\
\text { vulnerability of patients who } \\
\text { need kidney transplantation in } \\
\text { the state. }\end{array}$ & $\begin{array}{l}\text { There is increasing } \\
\text { vulnerability of people with } \\
\text { kidney disease and who need } \\
\text { transplantation in Alagoas as } \\
\text { evidenced in the interviewees' } \\
\text { statements. Still relying on } \\
\text { Foucault's biopower concept, }\end{array}$ \\
\hline
\end{tabular}


to realize how vulnerable these people are. It's a fact that it isn't recognized as public health problem of a chronic and insidious disease that afflicts the population on the part of the State that was omitted to its responsibility to institute comprehensive measures of protection to the ethical subject that needs.

(Victorino \& Ventura, 2017) Analyze the opinion of health professionals about the process of implementing Law $10.211 / 2001$ in a university hospital based on the ethicallegal perspective.
The donation and

transplantation of organs and tissues have undoubtedly become tools capable of guaranteeing life quality for the population that has some disease whose only treatment is the replacement of the organ. Transplantation legislation has undergone several changes since its inception and the most recent law, promulgated in 2001, establishes the donation of post-mortem organs only with family consent. This law still extinguishes all and any registration type in an official document that proves the option of being or not organ donor.

Source: Research data, 2020.

\section{Discussion}

There are five bioethical elements that support organ and tissue transplantation: autonomy, beneficence, dignity, justice, not maleficence. Autonomy includes the patient's right to reject or accept treatment, that is, self-determination. Beneficence addresses the transplantation team's commitment to prioritize the patient's integrity, without actions involving coercion and conflict of interest. Dignity is the maintenance of the patient's honor, integrity and self-esteem (Coffman \& Siemionow, 2014). Non-maleficence is a bioethical principle that assimilates the phrase: "First of all, do no harm". It encompasses the notion of performing transplantations not only for purposes, but to enhance functionality (Caplan, 2014) (Coffman \& Siemionow, 2014). 
Advances in surgical methods, expansion of pre- and post-operative care and introduction of immunosuppressive drugs have contributed greatly to the progress and proliferation of organ and tissue transplantation programs. However, the unfavorable balance of a demand higher than supply hampers the number of beneficiaries (Lara \& Rojas, 2014).

In Brazil, there is an increasing demand for the organs and tissues transplantation procedure, with a percentage increase of $74.8 \%$. The increase in demand requires greater investment in the training of the medical and surgical team, as well as higher expenses with infrastructure, equipment, specialized laboratories and medications used during the postoperative period, justifying the increase in expenses by the State, estimated at $163 \%$ (Batista \& Seidl, 2017).

Santos, Hossne and Anjos (2017) point to the decline of organ transplantation in all its stages in the state of Alagoas to the detriment of other states in the Brazilian northeastern, such as Ceará and Pernambuco, which show a positive growth of programs and transplantation consolidation. An increasing number of individuals donating organs and tissues for transplantation has been demonstrated, however, this increase does not satisfy the demand in Brazil, providing stagnation of the national waiting list (Victorino \& Ventura, 2017).

The transplantation legislation process differs among nations, with Laws number 9.434/ 1997 and 10.211/2001, with its decrees, ordinances and resolutions, the jurisprudence in force in Brazil, which enables the family to deliberate on the removal of organs and tissues for donation (Batista \& Seidl, 2017).

The Law number 9.434, of February 4, 1997, deals with the removal of organs, tissues, and parts of the human body for the purpose of transplantation and therapeutics. The article 6 (six) stands out, having as a transgression the removal of organs, tissues or any part of the human body from people not recognized in the post-mortem and also the article 15, which deals with the organs trade, sentencing the act as a crime with a punishment of three to eight years of imprisonment and fine (Batista \& Seidl, 2017) (Felipe, 2014) (Victorino \& Ventura, 2017).

Batista and Seidl (2017) establish that, from the need for transplantation as the only viable therapy for the patient, this one enters a unique national registry, being considered by Victorino and Ventura (2017) as an element of hope, because it allows a greater perspective of survival. This list has as evaluation criteria the severity of the state in which the patient is, being implemented to accelerate the process of finding a compatible donor. The National 
Transplant Center (CNT), along with the Centers for Notification, Collection and Distribution of Organs (CNCDO), orient the process organs and tissues allocation donated for transplantation (Batista \& Seidl, 2017).

With great importance as well, the article 2 of Ordinance 3407/98, among the 18 Ordinances related to transplantation procedures, states that: "organ and tissue transplantationss performed in public health units are financed by SUS, but there are also the possibility of realization in private health units depending on the costing by health insurance" (Batista \& Seidl, 2017).

Only the medical-surgical team, specialized in the organs removal for transplantation and its subsequent implantation in the viable receiver, recognized and authorized by the Unified Health System (SUS), can perform the procedure in a public or private healthcare unit, regulated by the Ministry of Health (Batista \& Seidl, 2017).

Patients who are candidates for organ and tissues transplantation are subjected to rigorous evaluation and, in most cases, they are individuals with serious and irreversible damage. Several factors influence a successful transplantation, such as: donor/receiver histocompatibility, waiting time, obtaining capacity, organization of organ transport, medicalsurgical situation, training and resource of the specialized center and economic cost (Batista \& Seidl, 2017) (Lara \& Rojas, 2014).

The desire to be a donor is not a habit discussed among people with their respective families, as with their partners or friends. This lack of communication and expression of will contributes to the decrease of organ donation, even with growing public policies and online campaigns (Caplan, 2014). The article 4 of the Law number 9.434, regulated by the Decree 2.268/1997, established a concession for organ donation in a presumed manner, except in contrary statements expressed in life by the potential donor. However, Law number 10.211, instituted in 2001, decreed exclusive authority to the family for the donation of organs and tissues of cadavers, even if there is disagreement with the desire of the individual manifested in life (Victorino \& Ventura, 2017).

In the United States, the United Kingdom, Denmark, Australia and other countries, the policy that govers organs and tissues donation is based on "encouraged volunteerism", constantly supported by public education campaigns. In Israel and Singapore, the primacy of access to transplantations in occasional need works as a complementary incentive to be a donor (Caplan, 2014). 
The organ donation is determined from the diagnosis of brain death (Avello \& Santos, 2014). The determination of encephalic death is based on the accomplishment of two clinical evaluations by doctors who aren't part of the medical-surgical group that performs the transplantation procedures, in different periods, integrated to the accomplishment of complementary exams for evaluation of cerebral cortical activity, perfusion and metabolism in accordance with CFM Resolution number 1480/1997 (Victorino \& Ventura, 2017).

But, in response to the stagnation in the number of donations and the increase in the list and waiting time, some countries consider the situation of "cardiac death" with the introduction of controlled asystole for organ donation, not considering it as contrary practice to medical ethics. However, the insertion of a new criterion raises discussions that address the waiting time for cessation of cardiovascular functions, donor manipulation before death and conflict of interests between donor/receiver (Avello \& Santos, 2014).

\section{Final considerations}

Faced with the death expectation, organs transplantation emerges as a safe method with the potential to increase longevity and quality of patient life, being considered a timely alternative to patients with end-stage organic disease if the organ or tissue is not transplanted.

The patient with indication for transplantation is an individual in great vulnerability, either to the one that responds to inadequate coverage and to the failures of the transplant stages, or to the very state of illness of the ethical subject. That said, the fragilities recognition based on autonomy, equity and prudence are crucial elements for the patient.

\section{References}

Avello, José Manuel Álvarez \& Santos, José Antonio (2014). Analysis of bioethical issues related to organ donation in controlled asystole programs. Acta Bioethica, Madrid, 20(1), p.09-21.

Batista, Katia Torres \& Seidl, Eliane Maria Fleury. (2017). Bioethical analysis of face transplantation in Brazil. Revista Brasileira de Cirurgia Plástica (rbcp) - Brazilian Journal Of Plastic Sugery, [s.1.], 32(3), p.421-427. GN1 Genesis Network.

Caplan, A. (2014). Bioethics of Organ Transplantation. Cold Spring Harbor Perspectives In Medicine, [s.1.], 4, n. 3, p.01-07, 29 jan. Cold Spring Harbor Laboratory. 
Coffman, Kathy L. \& Siemionow, Maria Z. (2014). Ethics of facial transplantation revisited. Current Opinion In Organ Transplantation, [s.1.], 19(2), p.181-187, abr. Ovid Technologies (Wolters Kluwer Health).

Felipe, Elaine Fernandes et al. (2014). Ethical aspects of teeth obtained by odontology graduates. Biomédica, Santa Catarina, 22(1), p.171-175, 06 mar.

Lara C, Libia, \& Rojas O, Alberto. (2014). Reflexión bioética sobre trasplantes de pulmón. Revista chilena de enfermedades respiratorias, 30(4), 219-224. https://dx.doi.org/10.4067/S0717-73482014000400005

Nunes, Lucília. (2017). The teaching of bioethics and the thematic choices of students. Revista Bioética, [s.1.], 25(3), p.512-526, dez. FapUNIFESP (SciELO).

Santos, Carlos Adriano Silva dos; Hossne, William Saad \& Anjos, Marcio Fabri dos. (2017). Kidney transplantation in Alagoas: a bioethical view regarding the vulnerability of those in need. Revista Bioética, [s.1.], 25(1), p.123-129, abr. FapUNIFESP (SciELO).

Victorino, João Paulo \& Ventura, Carla Aparecida Arena. (2017). Organ donation: a bioethical issue in the light of legislation. Revista Bioética, [s.1.], 25(1), p.138-147, abr. FapUNIFESP (SciELO).

\section{How to cite this article (APA format):}

Andrade, A. M. L. C. de; Modesto, C. P.; Albuquerque, L. T. C. de; Granja, T. A.; Albuquerque, A. B. T. C. de; Silva, C. G. L. da; Malheiro, D. R. (2020). Donation nd Transplantation of Organs and Tissues in a Bioethic Dimension: A Systematic Review. Am. In. Mult. J., Jul to Oct. (9) 5, 63-73.

Received: 07/27/2020

Accepted: 08/03/2020 